\title{
THE DETERMINANTS AFFECTING FRAUD TRENDS
}

\author{
Seto Satriyo Bayu Aji \\ Universitas 'Aisyiyah Yogyakarta \\ Email : setosatriyo06@gmail.com
}

\section{ARTICLE INFORMATION}

Article history:

Received August 03, 2017

Revised Dec 10, 2017

Accepted March 12, 2018

JEL Classifications

D73; K42; D49

\section{Key Words:}

Ethics,

Compensation Conformity,

Leadership Style,

Fraud

\section{DOI:}

10.21532/apfj.001.18.03.01.03

\begin{abstract}
This study aims to examine the determinants that influence the tendency of fraud in medium-sized companies in Yogyakarta. The variables used in this study are ethics, compensation conformity, leadership stlye, and fraud. The population in this study is medium-sized companies in Yogyakarta. Sampling is done by using purposive sampling method. The sample used is the staff of mediumsized companies in Yogyakarta. The research model uses SmartPLS 2.0 in proccesing data. The results of this study show that ethics has a negative effect on fraud; compensation conformity has a negative effect on fraud; and leadership style has a negative effect on fraud.
\end{abstract}

\section{INTRODUCTION}

Fraud, particularly in financial sector, has been spreading across all aspects of life, in which all lines have been affected by corruption. Indonesia is one of the most corrupt countries in the world. According to the Corruption Perception Index (CPI) 2014, published globally by Transparency International, Indonesia is a country with a high level of corruption. In the CPI 2014, Indonesia is ranked 117 th out of 175 countries in the world, with a score of 34 in a scale of $0-100(0=$ very corrupt and 100 $=$ very clean). Corruption occupies the top position out of 18 (eighteen) factors inhibiting the ease of business in Indonesia.

Fraud is a deliberate or careless act in doing or not doing something as it should be so that financial statements become materially misleading (Tuanakotta, 2010). Detecting fraud is not an easy task because it requires a comprehensive knowledge related to the characteristics and ways of doing fraud. According to Kassem and Higson (2012) the detection of fraud does not always get a bright spot due to the various underlying motivations and methods of doing fraud. The above information confirms that an auditor desperately needs an indicator, commonly 
called red flag, to detect the fraud risk. Red flag is a potential symptom that requires more indepth investigation, which indicates a higher risk of deliberate misstatement in financial statements. It can also be said that red flag is an early warning signal to reduce the risk of being undetected by auditors. SAS No. 99 requires external auditors to use 42 red flags in detecting possible fraud (Moyes 2006).

Fraud can be detected by looking at the determinants that affect the occurrence of fraud. However, it is inevitable that fraud risk still continues to happen in company. Fraud risk occurring in company can be prevented by applying ways as disclosed by Amrizal, (2011), such as examining and assessing the adequacy of the application of the management control system, internal control structure, and other operational control systems, developing effective control systems at the most appropriate and efficient cost, ensuring compliance with policies, plans and procedures established by management, and ensuring the reliability of the data management developed within the organization.

This research was conducted by exploring the perception of fraud trend in the Regional-Owned Enterprises in Yogyakarta and some factors that influence it. These factors include ethics, compensation conformity and leadership style.

The problems to be discussed in this research are formulated in the form of research questions as follows:

1. Does ethical behavior have an effect on the trend of fraud?

2. Does compensation conformity have an effect on the trend of fraud?

3. Does leadership style have an effect on the trend of fraud?

The purpose of this study is to find out the effect of the determinants, such as ethics, compensation conformity and leadership style, on the trend of fraud.

\section{THEORETICAL BASIS AND HYPOTHESIS DEVELOPMENT}

\section{Fraud}

In general, fraud involves a variety of meanings. By utilizing his intelligence, man can plan to gain profit through the wrong description. Fraud is a deliberate or careless act in doing or not doing something as it should be so that financial statements become materially misleading (Tuanakotta 2010). Meanwhile, the Association of Certified Fraud Examiners (ACFE) describes the branches of fraud as the form of a working relationship scheme resembling a tree and its twigs. There are three main branches, namely Corruption, Asset Misappropriation, and Fraudulent Statements

\section{Asset Misappropriation}

Asset misappropriation involves the misappropriation / theft of a company's or other parties' assets or properties. This is the most easily detectable form of fraud because it is tangible or can be measured.

\section{Fraudulent Statements}

Fraudulent statements include actions taken by an officer or executive of a company or government agency to cover the actual financial condition by performing financial manipulation in presenting the financial statements for profit. One form of fraudulent statements is earnings management (Rezaee, 2002).

\section{Corruption}

Corruption is prevalent in countries that have a weak law enforcement system, and a lack of awareness of good governance so that the integrity factor is questionable. This type of fraud is the most difficult to detect because it involves cooperation with other parties such as bribery and corruption that have a symbiotic relationship of mutualism. 


\section{Factors Affecting Fraud Trend}

From the above explanation there are several factors that can affect the trend in fraud, such as:

\section{Ethics}

According to Wilopo (2006), ethics is something that is difficult to understand, in which the answer depends on the complex interaction between the situation and the personal characteristics of the doers. Although it is difficult in the context of accounting and its relationship to the market is also often unclear, modeling behavior needs to be considered in order to improve the quality of decisions and reduce costs related to information, and improve the availability of information existing in the market (Hendriksen, 1992). Tang (2003) in his research describes distorted or unethical behavioral indicators in the company. According to Kusumastuti (2012), this ethics consists of abuse of power, abuse of position, abuse of resources, and no action)

\section{Compensation}

Odunlade, R.O (2012) discloses that the grant of compensation refers to all other forms of remuneration and other tangible benefits an employee receives in return for the employee's performance for the company. According to Dessler (1997), compensation refers to all forms of wages or benefits received by employees arising from work they have accomplished well, and have two main components of direct and indirect payments. Direct payments are usually in the form of overtime wages, basic salaries, premiums, incentives, commissions, bonuses, and benefits. Indirect payments are usually in the form of financial benefits such as insurance and holiday allowances paid by company, praise, oral appreciation, and a sense of security.

Odunlade, R.O (2012) says that employee compensation consists of basic salary and benefits. Meanwhile, McNamara
(2008) considers more detailed compensation that includes issues related to wages or salary programs and structures derived from job descriptions, service-based programs, bonusbased programs, commission-based programs and so on. According to Rabindra, N. and Medonca (in Nugraha, 2010), compensation conformity is the level of conformity to all forms of return both financially and nonfinancially received by employees due to the services donated to the company.

\section{Type of Compensation}

According to Hasibuan (2007), compensation is divided into two:

\section{a. Direct Compensation}

Direct compensation consists of:

1) Salary: remuneration paid periodically to permanent employees and has the right insurance.

2) Wages: remuneration paid to daily workers on the basis of an agreement.

3) Incentive wages: additional money paid to certain employees whose performance is above the standard performance.

\section{b. Indirect Compensation}

Indirect compensation consists of employee protection, employee benefits, and employee comfort. In providing compensation, it is necessary to apply principles that can facilitate the company in the process of providing compensation to employees. These principles, according to Siagian (2008), are as follows:

\section{a. Principle of Justice}

Determining the principle of justice is not easy. So, it is necessary to use four comparative criteria:

1) Assessing whether the rewards received are appropriate or not with the expectation. 
2) Comparing the rewards he or she has received while working elsewhere.

3) Comparing the amount and type of benefits received with those received by a co-worker under the same qualified assumptions.

4) Comparing with reward system in other companies in the same field.

\section{b. Principle of Fairness}

This means that the amount of compensation provided allows the employee and his family to maintain a proper lifestyle in accordance with their social position and dignity in the company and in society.

\section{c. Principle of Equality}

If the labor market applies a specified wage and salary rate, among others through the agreement of the labor user association, this principle will be easy to implement.

\section{d. The Principle of Organizational Capability}

In granting compensation, the company should consider its own ability, because the compensation must be adjusted to the company's financial condition.

\section{Leadership Style}

Leadership is a tool that arranges an organization to achieve the goals of the company (Johannes, 2016). Thus, many management experts put forward various opinions on the definition of leadership. As stated by Hasibuan (2009), the leadership set by a manager in the organization can create a harmonious integration and encourage employee enthusiasm to achieve maximum goals. Leadership is the way how a leader influences the behavior of subordinates to be willing to work together and work productively to achieve organizational goals.
According to Adair (2010), leadership is specific in accordance with the particular situation observed. Those who become the leaders of a particular group must engage in a particular activity, and the leadership characters that play a role in a particular case are a function of a specific situation. At the same situation, there are different characteristics of individuals who become leaders and, at the different situation, the differences in the characteristics will be even greater. Wursanto (2003) provides the formulation that leadership is an activity affecting others to work together to achieve certain desired goals.

The leadership style is the style of leadership brought about by a leader in influencing his followers. The style of a leader in carrying out his leadership is influenced by various patterns (Wursanto, 2003), such as education pattern, experience pattern, age pattern, and character pattern. A leader who does not master the field of duty existing in his authority will submit everything to his subordinates, so that his leadership style is called Laissez faire (Prasastono, 2012).

\section{Hypothesis Formulation}

From the explanation above, the hypotheses can be formulated as follows:

H1: Ethics has a negative effect on the trend of fraud.

$\mathrm{H} 2$ : Compensation conformity has a negative effect on the trend of fraud.

H3: Leadership style has a negative effect on the trend of fraud 


\section{Figure 1}

Framework

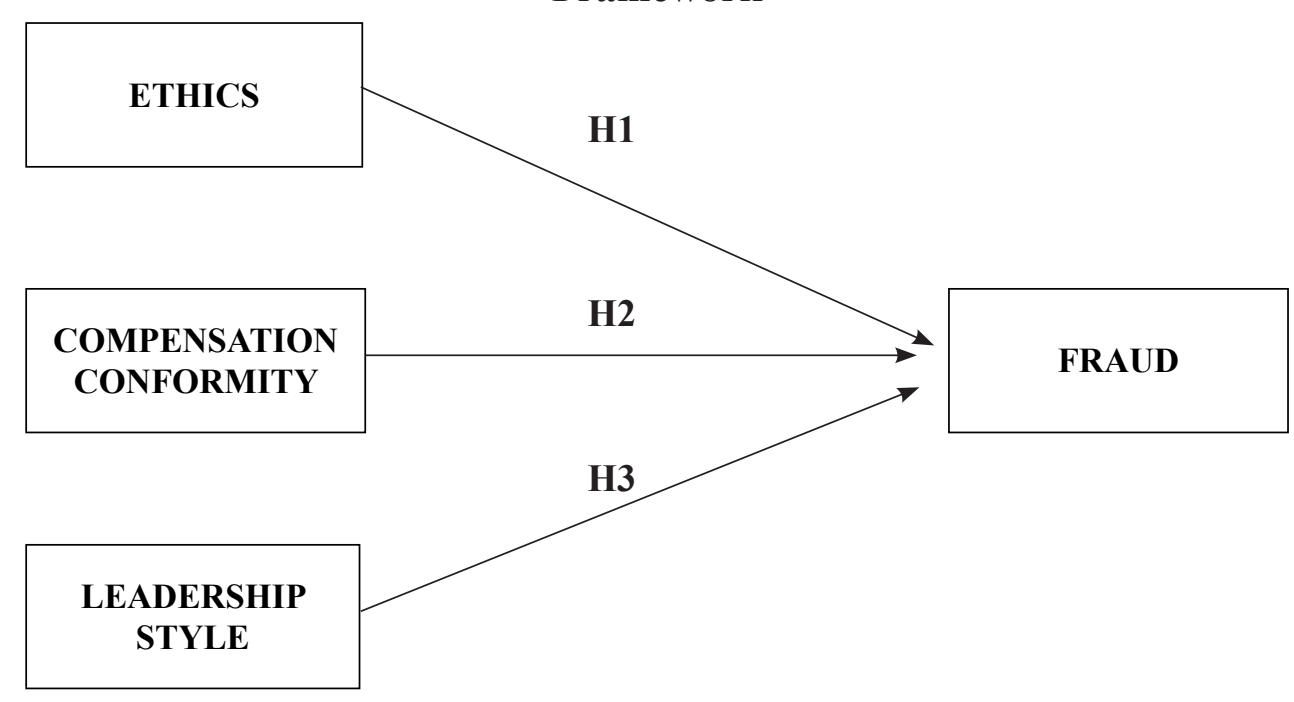

\section{RESEARCH METHOD}

The research method used is survey method. Survey method is the primary data collection method between researchers and respondents. Data collection using survey method is designed to explain the cause and effect relationship.

Due to limited time and cost, the object of this research is only focused on medium-sized companies located in Yogyakarta. Besides, the author assumes that the existence of mediumsized companies existing in in Special Region of Yogyakarta (DIY) can thoroughly become national benchmark.

This research uses 2 data processings: descriptive analysis and analytical analysis. Analysis related to the explanation of various behavioral variables is done by using descriptive analysis based on various relevant theories and approaches. Analysis that has interrelationship between various variables is done by using statistical test approach in the form of simultaneous equation model (SEM) which is assisted by smartPLS application program version 2.0.

\section{DATA ANALYSIS AND DISCUSSION}

\section{Validity Test}

Validity test in this research involves convergent validity and discriminant validity. Individual reflective measure is said to be high if it has correlated value of more than 0.5 . (With significance level of 0.05 and $\mathrm{T}$ statistic value $>1.64)$.

Meanwhile, the validity test that involves discriminant validity is done by comparing the AVE (average variance extracted ) square root value of each construct with the correlation between the construct and the other constructs in the model. If the AVE square root of each construct is greater than the correlation value between the construct and the other constructs in the model, it has a good discriminant validity value. 
Table 4.4

Initial Item Loadings and AVE

\begin{tabular}{|c|l|c|c|c|}
\hline Variable & Items of Question & Code & Loading & AVE \\
\hline \multirow{3}{*}{$\begin{array}{c}\text { Ethics } \\
\text { (ETC) }\end{array}$} & Use of official vehicles & ETC1 & 0.508 & \\
\cline { 2 - 4 } & Photocopy for personal use & ETC2 & 0.525 & \multirow{2}{*}{0.319} \\
\cline { 2 - 4 } & Taking a vacation using office facilities & ETC3 & 0.753 & \\
\cline { 2 - 4 } & Employee attitude toward harmful action & ETC4 & 0.714 & \\
\hline
\end{tabular}

\begin{tabular}{|c|c|c|c|c|}
\hline \multirow{7}{*}{$\begin{array}{c}\text { Compensation } \\
\text { Conformity } \\
(\mathrm{COM})\end{array}$} & Items of Question Item & Code & Loading & AVE \\
\hline & Compensation based on achievement & COM1 & 0.625 & \multirow{6}{*}{0.344} \\
\hline & Individual responsibility & COM2 & 0.543 & \\
\hline & Promotion based on achievement & COM3 & 0.536 & \\
\hline & $\begin{array}{l}\text { The company is managed by using good } \\
\text { management }\end{array}$ & COM4 & 0.732 & \\
\hline & Timely financial statements & COM5 & 0.635 & \\
\hline & Compatibility between work and expertise & COM6 & 0.647 & \\
\hline
\end{tabular}

\begin{tabular}{|c|l|c|c|c|}
\hline \multirow{4}{*}{ Variable } & Items of Question & Code & Loading & AVE \\
\hline \multirow{4}{*}{$\begin{array}{c}\text { Leadership Style } \\
\text { (LDS) }\end{array}$} & Leadership firmness & LDS1 & 0.662 & \\
\cline { 2 - 4 } & Work instructions on subordinates & LS2 & 0.513 & \multirow{2}{*}{0.524} \\
\cline { 2 - 4 } & Delegation of authority & LDS3 & 0.637 & \\
\cline { 2 - 4 } & Openness in getting advice & LDS4 & 0.543 & \\
\cline { 2 - 4 } & Giving bonus by superiors & LDS5 & 0.542 & \\
\hline
\end{tabular}

\begin{tabular}{|c|l|c|c|c|}
\hline \multirow{1}{*}{ Variable } & Items of Question & Kode & Loading & AVE \\
\hline \multirow{4}{*}{ Fraud (FRD) } & Decreasing the cost on the report & FRD1 & 0.504 & \\
\cline { 2 - 4 } & Eliminating bookkeeping documents & FRD2 & 0.540 & \multirow{3}{*}{0.435} \\
\cline { 2 - 4 } & Minimizing reserve receivables & FRD3 & 0.642 & \\
\cline { 2 - 4 } & Receiving fictitious payments & FRD4 & 0.588 & \\
\cline { 2 - 4 } & Courage to reject unnatural requests & FRD5 & 0.579 & \\
\hline
\end{tabular}


Table 4.5

Cross Loading

\begin{tabular}{|c|c|c|c|c|}
\hline & ETC & $\mathrm{COM}$ & LDS & FRD \\
\hline ETC1 & 0.714 & 0.437 & 0.549 & 0.296 \\
\hline ETC2 & 0.761 & 0.447 & 0.503 & 0.195 \\
\hline ETC3 & 0.738 & 0.414 & 0.456 & 0.296 \\
\hline ETC4 & 0.716 & 0.166 & 0.626 & 0.486 \\
\hline COM1 & 0.251 & 0.778 & 0.225 & 0.104 \\
\hline COM2 & 0.366 & 0.746 & 0.301 & 0.109 \\
\hline COM3 & 0.362 & 0.754 & 0.340 & 0.444 \\
\hline COM4 & 0.283 & 0.709 & 0.235 & 0.080 \\
\hline COM5 & 0.316 & 0.766 & 0.826 & 0.586 \\
\hline COM6 & 0.710 & 0.747 & 0.703 & 0.195 \\
\hline LDS1 & 0.638 & 0.414 & 0.756 & 0.296 \\
\hline LDS2 & 0.416 & 0.166 & 0.826 & 0.286 \\
\hline LDS3 & 0.103 & 0.251 & 0.729 & 0.706 \\
\hline LDS4 & 0.517 & 0.166 & 0.826 & 0.786 \\
\hline LDS5 & 0.366 & 0.166 & 0.856 & 0.186 \\
\hline FRD1 & 0.713 & 0.241 & 0.625 & 0.697 \\
\hline FRD2 & 0.701 & 0.239 & 0.630 & 0.897 \\
\hline FRD3 & 0.418 & 0.166 & 0.326 & 0.756 \\
\hline FRD4 & 0.623 & 0.241 & 0.625 & 0.697 \\
\hline FRD5 & 0.573 & 0.239 & 0.630 & 0.797 \\
\hline
\end{tabular}

Source: Processed data

Table 4.4 explains that the constructs of Ethics (ETC), Compensation Conformity (COM), Leadership Style (LDS) and Fraud (FRD) produce AVE and loading factor more than 0.5 . From the data, it can be concluded that the indicators used in this research are valid or have fulfilled the convergent validity.

In Table 4.5, the discriminant validity of reflective indicator is tested using cross loading where it is stated that an indicator is declared 'valid' if the loading factor of the target construct is higher than that of another construct. The table shows that the loading factor for the majority LDS indicator is higher than the other constructs.

\section{Reliability Test}

The reliability of existing construct data can be measured using composite reliability. The construct is declared 'reliable' if the value of composite reliability is above 0.70 . The following is the calculation of construct summarized in internal composite reliability and correlation among constructs: 
Table 4.6

Internal Composite Reliability and Correlation among Constructs

\begin{tabular}{|c|c|c|c|c|c|}
\hline & CR & ETC & COM & LDS & FRD \\
\hline ETC & 0.778 & $\mathbf{0 . 7 5 8}$ & & & \\
\hline COM & 0.876 & 0.533 & $\mathbf{0 . 7 4 7}$ & & \\
\hline LDS & 0.866 & 0.641 & 0.360 & $\mathbf{0 . 7 7 9}$ & \\
\hline FRD & 0.776 & 0.595 & 0.295 & 0.570 & $\mathbf{0 . 7 6 7}$ \\
\hline
\end{tabular}

Source: Processed data

Note: the bold elements on the main diagonal are the square root of the AVE.
ETC : Ethics
COM : Compensation Conformity
LDS : Leadership Style Gaya
FRD : Fraud

The table above shows that the value of composite reliability for all constructs is above 0.70 indicating that all constructs in the estimated model meet the discriminant validity criteria. The lowest composite reliability value is 0.876 , that is, on the Compensation Conformity (COM)

\section{Hypotheses Testing \\ Hypothesis 1 (H1): Ethics has a negative effect on Fraud}

Table 4.8 and Figure 4.1 show that the relationship between ethics (ETC) and fraud (FRD) is not significant with the coefficient path of -0.955 and $t$-value of 4.325 ( $>1.64)$. The result of hypothesis 1 testing gives an illustration that ethics has a negative effect on fraud. This result supports the result of the research conducted by Thoyibattun (2012) that unethical behavior can affect the occurrence of fraud, or in other words ethics has a negative effect on fraud. Thus H1 in this study, which states that ethics has a negative effect on fraud, means that if an organization has a good ethics it will minimize the tendency to commit fraud.

\section{Hypothesis 2 (H2): Compensation Conformity has a negative effect on fraud}

Table 4.8 and Figure 4.1 show that the relationship between compensation conformity (COM) and fraud (FRD) is not significant with the coefficient path of -0.033 and t-value of $1.524(<1.64)$. The result of hypothesis 2 testing gives an illustration that compensation conformity has no effect the occurrence of fraud in an organization. This result is in accordance with the result of the research conducted by Wilopo (2006) and Zulkarnain (2013) that compensation conformity has no effect on the occurrence of fraud. Thus H2 in this study, which states that compensation conformity has a negative effect on Fraud, means that if an organization provides appropriate compensation, the tendency to commit fraud will decrease.

\section{Hypothesis 3 (H3): Leadership style has a negative effect on fraud}

Table 4.8 and Figure 4.1 show that the relationship between leadership style (LDS)) and fraud (FRD) is not significant with the coefficient path of -0.753 and t-value of 1.815 $(>1.64)$. The result of this hypothesis 3 testing gives an illustration that leadership style has a negative effect on the occurrence of fraud in 
an organization. This result is in accordance with the result of the research conducted by Pramudita (2013) in which leadership style has a negative effect on fraud. Thus H3 in this study, which states that leadership style has a negative effect on the occurrence of fraud, means that if an organization has a good leadership style, it can suppress the occurrence of fraud in an organization.

Table 4.9

Conclusion of the Hypotheses

\begin{tabular}{|c|c|c|c|c|}
\hline Hypothesis & Relationship & $\boldsymbol{\beta}$ & t-Value & Result \\
\hline H1 & ETC-> FRD & -0.955 & 4.325 & Supported \\
\hline H2 & COM -> FRD & -0.033 & 1.524 & Supported \\
\hline H3 & LDS -> FRD & -0.753 & 1.815 & Supported \\
\hline
\end{tabular}

Source: Processed data

Figure 4.1

Result of the Research

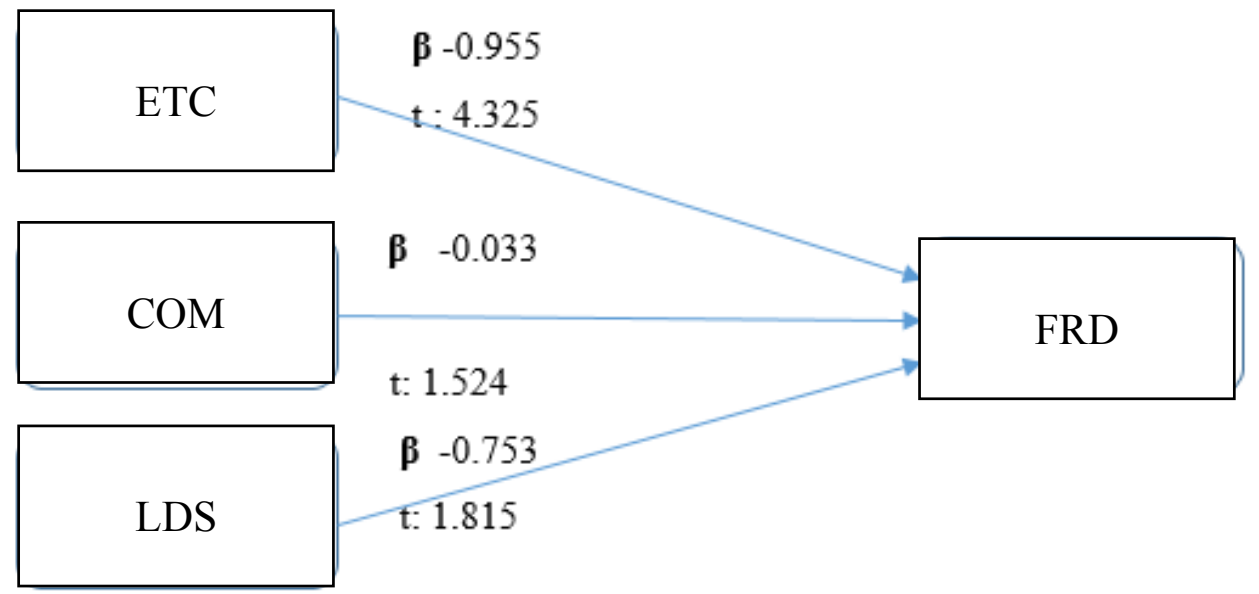

\section{CONCLUSION AND SUGGESTION}

\section{Conclusion}

From the results of the discussion in this study, it can be drawn conclusion as follows:

1. Ethics has a negative effect on fraud, which means that if an organization has good ethics, the tendency to commit fraud will be less.

2. Compensation conformity has a negative effect on fraud, which means that if the compensation is appropriate, the desire to commit fraud will be reduced.
3. Leadership style has a negative effect on fraud, which means that if the leadership style is good, it can suppress the desire of the subordinates to commit fraud.

\section{Suggestion}

Here are some suggestions that can be put forward for further researchers:

1. Expanding the research object on other industries as well as on other organizations so that it can be developed further.

2. Developing and adding other factors that are expected to affect the fraud 
and provide additional research in the future

\section{Research Implication}

Fraud is detrimental and should be prevented. This research is expected to provide knowledge about fraud prevention and become a reference for subsequent research.

\section{REFERENCES}

ACFE " Fraud Examiners Manual, Third Edition 2000

Adair, John. 2000. Bukan Bos Tetapi Pemimpin. Jakarta: PT Gramedia Pustaka Utama.

Albrecht W.Steve and Albrecht Chad O, 2003. "Fraud Examination Thomson SouthWestern.

Amrizal. 2011. Pencegahan dan Pendeteksian Kecurangan oleh Internal Auditor

Firdaus, Eka \& Erni Suryandari. 2008. Pengaruh Faktor Kultur Organisasi, Manajemen, Strategi, Keuangan, Auditor Dan Pemerintahan Terhadap Kecenderungan Kecurangan Akuntansi. Jurnal Akuntansi dan Investasi Vol. 9 No. 2, halaman: 173188

Ghozali, Imam.2008."Structural Equation Modeling Metode Alternatif denganPartial Least Square."Semarang : Badan Penerbit Universitas Diponegoro Hasibuan, Malayu, 2005, Manajemen Sumber Daya Manusia, Edisi Revisi PT. Bumi Aksara. Jakarta

Hendriksen, Eldon.S dan M.F.van Breda. 2000. Teori Akuntansi. Batam: Interaksara

Johannes, Andrew \& Adolfina Taroreh. 2016. Pengaruh Gaya Kepemimpinan, Kompensasi, Dan Lingkungan Kerja Terhadap Kinerja Agen Pada Ajb Bumiputera 1912 Cabang Tikala. Jurnal Berkala Ilmiah Efisiensi. Volume 16 No. 01.
Kassem, R. dan A. Higson. 2012. "The New Fraud Triangle Model”. Journal of Emerging Trends in Economics and Management Sciences, Vol. 3, No. 3, hlm 191-195.

Kusumastuti, Nur Ratri. 2012. Analisis FaktorFaktor yang Berpengaruh Terhadap Kecenderungan Kecurangan Akuntansi Dengan Etika Sebagai Variabel Intervening. Semarang: Universitas Diponegoro

McNamara, C. 2008. Employee benefits and compensation: Basics about employee motivation: Nuts-and-bolts guide to leadership and supervision in business. Minneapolis, Minnesota Journal: Authenticity Consulting LLC.

Moyes, G.D., P. Lin, R.M. Landry, dan H. Vicdan. 2006. "Red Flags Detecting Fraud". Journal of Accounting, Ethics \& Public Policy, Vol. 6, No. 1, hlm 1-28

Mulyadi. 2008. Auditing. Edisi Keenam. Jakarta: Salemba Empat

Odunlade, R.O. 2012. Managing Employee Compensation and Benefits for Job Statisfaction in Libraries and Information Centres in Nigeria. Journal. Universitas of Lagos Nigeria.

Pramudita, Aditya. 2013. "Faktor-Faktor yang Mempengaruhi Terjadinya Fraud di Sektor Pemerintahan (Persepsi Pegawai pada Dinas se-Kota Salatiga)". Universitas Negeri Semarang

Prasastono, Ndaru. 2012. Pengaruh Gaya Kepemimpinan Dan Kompensasi Terhadap Motivasi Kerja Karyawan Hotel Muria Semarang. Dinamika Kepariwisataan Vol. XI No. 2

Rezaee, Z. 2002. Financial Statement Fraud: Prevention and Detection. New York: John Wiley \& Sons, Inc.

Siagian, S. P. 2008. Manajemen Sumber Daya Manusia. Jakarta: Bumi Aksara. 
Sugiyono, 2012.Metode Penelitian Bisnis. Tuanakotta, T. M. 2007. Akuntansi Forensik Alfabeta, Bandung. dan Audit Investigasi. Jakarta :Lembaga

Tang, T. L. P. and Randy K. Chiu, 2003. Income, Money Etic, Pay Satisfaction, Commitment, and Unethical Behavior: Is the Love of Money the Root of Evil for Hong Kong Employees? Journal of Business Ethics, 46, pp: 13-20.

Thoyibatun, Siti. 2012. Faktor-Faktor Yang Berpengaruh Terhadap Etika Dan Kecenderungan Kecurangan Akuntansi Serta Akibatnya Terhadap Kinerja Organisasi.Jurnal Ekonomi Dan Keuangan. Vol. 16, No.2 Penerbit Fakultas Ekonomi Universitas Indonesia

Wilopo. 2006. Analisis Faktor-Faktor Yang Mempengaruhi Kecenderungan Kecurangan Akuntansi. Simposium Nasional Akuntansi IX.

Wursanto, Ig. 2003. Dasar-Dasar Ilmu Organisasi. Yogyakarta: PT Andi Offset.

Zulkarnain, Rifki. 2013. Faktor - Faktor Yang Mempengaruhi Terjadinya Fraud Di Sektor Pemerintahan. Universitas Negeri Semarang 
Seto Satriyo Bayu Aji : The Determinants Affecting Fraud Trends.....

Page 21-31 